\title{
Impact of Foliar Application with Salicylic Acid on Biochemical Characters of Canola Plants under Cold Stress Condition
}

\author{
Hamed KESHAVARZ1 ${ }^{1}$ Seyed Ali Mohammad MODARRES SANAVY', \\ Ramin SADEGH GHOL MOGHADAM ${ }^{2}$

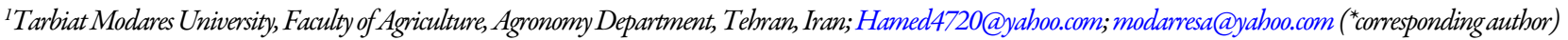 \\ ${ }^{2}$ Islamic Azad University, Plant Breeding Department, Karaj, Iran; Ramin_mo2005@yahoo.com
}

\begin{abstract}
In this study the effect of foliar application of salicylic acid on the chlorophyll content, antioxidant enzymes activity, and the content of solute protein and proline were investigated in two canola varieties (Brassica napus L., cv 'RGS' and 'Licord') leaves during 0, 24 , and 48 hours after salicylic acid treatment. The results showed that the content of total chlorophyll was decreased in 'RGS' cultivar during the experiment and this process was related with increasing of salicylic acid concentration. The activity of superoxide dismutase, peroxidase, and also lipid peroxidation were increased significantly after 48 hours compared with the first day. The results of catalase activity showed that, this trait was decreased 24 hours after salicylic acid treatment and this decrease was related with salicylic concentration. The content of protein in both cultivars slightly changed and plants treated with salicylic acid had more protein content, by contrast proline was greatly affected by salicylic acid treatment and its content was the highest 24 hours after treatment. According to the present findings the application of salicylic acid has useful effects on the biochemical traits of Brassica napus cultivars. Therefore it may be effective for the improvement of plant growth in cold regions.
\end{abstract}

Abbreviation: CAT-Catalase; Chl-Chlorophyll; SA-Salicylic acid; SOD-Superoxide dismutase; POX-Peroxidase; ROSReactive Oxygen Species.

Keywords: antioxidant enzymes, cold stress, oxidative damage, photosynthetic pigments, salicylic

\section{Introduction}

It is a well know that, low concentration of phytohormones could control the wide range of growth and development process (Yamamuro et al., 2016). However, the metabolic aspects of plants grown under applied phytohormones changed to varied degrees depend on the plant type and action mode (Yamamuro et al., 2016). Salicylic acid belongs to a group of plant phenolics which has an aromatic ring and natural product of phenylpropanoid metabolism. SA is involved in plant growth, flower induction, termogenesis and affects ions uptake (Raskin, 1992). Enhancement the pigments content of photosynthetic rate (chlorophyll and carotenoids) and modifying the activity of some important enzymes are other roles of SA (Ruelland et al., 2016). In terms of stress physiology, SA was first demonstrated to play a role in responses to biotic stress and is involved in signal transduction process of biotic stress tolerance (Ruelland et al., 2016). In addition, acts as a signal for development of hypersensitive reaction (Horváth $e t$ al., 2007). However, it was gradually found to have more effects that could be of importance for other stress. Several studies show the ability of SA to produce protective effects in plant response to abiotic stress factors (Arivalagan and Somasundaram, 2015). The results of several studies shown that exogenous application of SA can aid plant tolerance with many abiotic stresses, such as: induced the increase in resistance to salinity (Szepesi et al., 2005), low temperature (Janda et al., 1997), water deficit (Singh and Usha, 2003), freezing (Tasgin et al., 2003) and heavy metal (Mishra and Choudhuri, 1999). Exogenous application reduced the inhibitory effect of heavy metal in rice (Oryza sativa L.) (Mishra and Choudhuri, 1999). In wheat, seeds were soaked in acetyl salicylic acid and the plants had better resistance to drought stress (Singh and Usha, 2003). In tobacco growth in medium containing SA was observed an increase in heat tolerance (Dat et al., 2000). It was shown that SA treatment applied to hydroponics growth solution of maize plants provide protection against low temperature stress (Mishra and Choudhuri, 1999). In addition SA is involved in resistance to salinity stress in tomato plants (Szepesi et al., 2005).

The genus Brassica is an important agriculture crop grown primarily for edible oil and used for various purposes, as vegetable, fodder, and condiments. Furthermore, it is known that Brassica species are significant plant for investigation in resistance of abiotic stress, especially cold resistance, and great advances have been made in term of cold induced genes and antioxidant mechanisms (Wang et al., 2007). 
In stress condition (low temperature especially), the primary target of damages are related to the photosynthesis and photoinhibition of photosynthesis causes the generation of ROS in the thylakoid membranes (Arivalagan and Somasundaram, 2015). These free radicals are able to damage the photosynthetic protein and pigments. In order to alleviated or prevent damage of free radicals, plants have evolved mechanisms by accumulation of low molecular weight solutes (Horváth et al., 2007) and antioxidant compounds (Tasgin et al., 2003), such as: SOD, CAT, and POX that scavenge the ROS. SOD is metallo-enzymes that scavenge the toxic superoxide radicals and catalyze the conversion of two superoxide anions into oxygen and $\mathrm{H}_{2} \mathrm{O}_{2}$ (Qaiser et al., 2010). Then, CAT converts the $\mathrm{H}_{2} \mathrm{O}_{2}$ into water and oxygen. POD decomposes $\mathrm{H}_{2} \mathrm{O}_{2}$ by oxidation of cosubstrates, such as: phenolic compounds and antioxidants (Ebrahimia et al., 2014).

The current research was conducted in order to determine the effect of salicylic acid treatment in two canola varieties and to add more information on the physiological traits under cold stress. For this goal, it has been investigated the changes in enzymes activity status, proline accumulation, protein solution, lipid peroxidation and chlorophyll pigments, related to defence strategies in each variety.

\section{Materials and Methods}

\section{Biological material and treatments}

Seeds of canola (Brassica napus L.) used in this experiment were surface sterilized, then washed several times with distilled water. Ten sterilized canola seeds were sown in $20 \mathrm{~cm}$ diameter of plastic pots filled with clay/organic/perlit (3/1/1, v/v/v) mixture and placed under controlled environment conditions with a day/night temperature of $22 / 20^{\circ} \mathrm{C}$ for one month with a $16 \mathrm{~h}$ daily light period (supplemented, if necessary, by $400 \mathrm{~W}$ sodium lamps). For SA treatment, thirty day old plants were spraying by salicylic acid. For cold stress treatment the plots were performed in a freezing chamber at $-2^{\circ} \mathrm{C}$ for 3 days (after $24 \mathrm{~h}$ of salicylic treatment). The cold treatment was carried out in a Conviron PGV-36 chamber (Controlled Environments Ltd) at $-2^{\circ} \mathrm{C}$ with a photosynthetic photon flux density of $250 \mu \mathrm{mol} \mathrm{m}$ ${ }^{2} \mathrm{~s}^{-1}$ provided by metal halide lamps and a $12 \mathrm{~h}$ photoperiod. Based on a preliminary experiment, the optimum concentrations for pre-treatments were: 100,200 and $400 \mu \mathrm{M}$ salicylic acid. Plants treated with similar volume of distilled water were used as controls. Some of the plants were pre-treated with 50, 100, 500 and $5000 \mu \mathrm{M}$ SA by spraying for $1 \mathrm{~d}$ at $22 / 20^{\circ} \mathrm{C}$. Preliminary experiments showed that treatment with 50 and $500 \mu \mathrm{MSA}$ was not reproducibly effective, while higher concentrations (5000 $\mu \mathrm{M}$ ) often caused visible damage to the plants after $5 \mathrm{~d}$ of treatment under normal growth conditions. The plants were firstly sprayed by $100 \mathrm{~cm}^{3}$ of the appropriate solution or water and then were transferred to the chamber. To determine the biochemical changes, the leaves were sampled after 0,24 and $48 \mathrm{~h}$ of chilling.

\section{Chlorophyll assay}

According to the method of Arnon (1949), chlorophyll was extracted in $80 \%$ acetone from leaves. Extracts were filtrated and content of total Chl was determined by spectrophotometry at 645 and $663 \mathrm{~nm}$. The content of Chl was expressed as $\mathrm{mg.g}^{-1}$ FW.

Total chlorophyll $=(0.0202) \times($ A.645 $)+(0.00802) \times($ A.663 $)$
Malondialdehyde assay

The level of lipid peroxidation was analysed in terms of malondialdehyde (MDA) contents reacting to thiobarbituric acid (TBA) reactive substance using the method of De Vos et al. (1991). Samples were homogenized in an aqueous solution of TBA $(10 \% \mathrm{w} / \mathrm{v})$ and $1 \mathrm{ml}$ aliquot of appropriately diluted sample was added to a test tube with an equal volume of either thiobarbituric acid (TCA) solution containing $25 \%(\mathrm{w} / \mathrm{v}) \mathrm{TCA}$, then mixtures were heated at boiling water $\left(95^{\circ} \mathrm{C}\right)$ for $25 \mathrm{~min}$. The amount of MDA was determined from the absorbance of the supernatant at 532 and $600 \mathrm{~nm}$. The content of MDA was determined using the extinction coefficient of MDA $(\varepsilon=155 \mu \mathrm{M}$ $\left.{ }^{-1} \mathrm{~cm}^{-1}\right)$.

\section{Preparation enzyme of extracts}

Leaf samples $(0.2 \mathrm{~g})$ were homogenized in a mortar and pestle with $3 \mathrm{ml}$ ice cold extraction buffer $(50 \mathrm{mM}$ potassium phosphate, $\mathrm{pH} 7$ ). The homogenate was centrifuged at $18000 \mathrm{~g}$ for $30 \mathrm{~min}$ at $4{ }^{\circ} \mathrm{C}$ then the supernatant was filtered through filter paper. The supernatant fraction was used as a crude extract for the assay of enzyme activity and PROT content. All operations were carried out at $4^{\circ} \mathrm{C}$.

\section{Assay of antioxidant enzymes activity}

Enzyme activities were measured at $25{ }^{\circ} \mathrm{C}$ using a spectrophotometer model Variam Cary Win UV 6000i, Australia.

Superoxide dismutase activity was determined according to the method of Giannopolitis and Ries (1977). The reaction mixture contained $100 \mu \mathrm{l} 1 \mu \mathrm{M}$ riboflavin, $100 \mu \mathrm{l} 12 \mathrm{mM} \mathrm{L}$ methionine, $100 \mu \mathrm{l} 50 \mathrm{mM} \mathrm{Na}_{2} \mathrm{CO}_{3}(\mathrm{pH} 10.2)$, and $100 \mu \mathrm{l} 75$ $\mu \mathrm{M}$ nitro blue tetrazolium (NBT) in $2.3 \mathrm{ml} 50 \mathrm{mM}$ potassium phosphate buffer ( $\mathrm{pH} 7$ ), with $200 \mu \mathrm{l}$ crude enzyme extract in a final volume of $3 \mathrm{ml}$. SOD activity was assayed by measuring the ability of the enzyme extract to inhibit the photochemical reduction of NBT (with some modification). Glass test tubes containing the mixture were illuminated with a fluorescent lamp $(120 \mathrm{~W})$; identical tubes that were not illuminated served as blanks. After illumination for $15 \mathrm{~min}$, the absorbance was measured at $560 \mathrm{~nm}$. Blank were run in the same way but without illumination. One unit of SOD was defined as the amount of enzyme activity that was able to inhibit by $50 \%$ the photoreduction of NBT to purple formazan. The SOD activity of the extract was expressed as SOD units per milligram of protein.

Peroxidase activity was determined by the oxidation of guaiacol in the presence of $\mathrm{H}_{2} \mathrm{O}_{2}$. The increase in absorbance at $470 \mathrm{~nm}$ was recorded for $1 \mathrm{~min}$ (Ghanati et al., 2002). The reaction mixture contained $100 \mu \mathrm{l}$ crude enzyme, $500 \mu \mathrm{l} 5 \mathrm{mM}$ $\mathrm{H}_{2} \mathrm{O}_{2}, 500 \mu \mathrm{l}$ guaiacol $28 \mathrm{mM}$, and $1.9 \mathrm{ml} 50 \mathrm{mM}$ potassium phosphate buffer ( $\mathrm{pH} 7)$. POX activity of the extract was expressed as POX units per milligram protein.

Catalase activity was estimated by the method of Cakmak and Horst (1991). The reaction mixture contained $100 \mu \mathrm{l}$ crude enzyme extract, $500 \mu \mathrm{l} 10 \mathrm{mM} \mathrm{H} \mathrm{O}_{2}$, and $1.9 \mathrm{ml} 50 \mathrm{mM}$ potassium phosphate buffer. The decrease in the absorbance at $240 \mathrm{~nm}$ was recorded for $1 \mathrm{~min}$. CAT activity of the extract was expressed as CAT units per milligram of protein.

\section{Protein assay}

Total protein content was determined using bovine serum albumin (BSA) as a standard, as described in Bradford (1976), 
100

using $1 \mathrm{ml}$ Bradford solution and $100 \mu \mathrm{l}$ crude extract. The protein concentration was calculated from a BSA standard curve.

\section{Proline assay}

Proline content was determined according to the method of Bates et al. (1973) which was modified as follows. Samples of leaves $(0.2 \mathrm{~g})$ were homogenized in a mortar and pestle with $3 \mathrm{ml}$ sulphosalicylic acid $(3 \% \mathrm{w} / \mathrm{v})$, and then the homogenate was centrifuged at $18000 \mathrm{~g}$ for $15 \mathrm{~min} .2 \mathrm{ml}$ of the supernatant were then put into a test tube which $2 \mathrm{ml}$ contained glacial acetic acid and $2 \mathrm{ml}$ freshly prepared acid ninhydrin solution $(1.25 \mathrm{~g}$ ninhydrin dissolved in $30 \mathrm{ml}$ glacial acetic acid and $20 \mathrm{ml} 6 \mathrm{M}$ orthophosphoric acid) were added. Tubes were incubated in a water bath for $1 \mathrm{~h}$ at $100^{\circ} \mathrm{C}$, and then allowed to cool at room temperature. After that $4 \mathrm{ml}$ of toluene were added and mixed on a vortex mixer for $20 \mathrm{~s}$. The test tubes were allowed to stand for at least $10 \mathrm{~min}$ to allow the separation of the toluene and aqueous phases. The toluene phase was carefully pipetted out into a glass test tube, and its absorbance was measured at $520 \mathrm{~nm}$ in a spectrophotometer. The content of proline was calculated from a PROL standard curve and was expressed as $\mathrm{mg} \mathrm{g}^{-1}$ per fresh weight.

\section{Statistical analysis}

All data were analysed using SAS software (SAS Institute Inc. 2002). Each treatment was analysed in three replications and the analyses of the variance (ANOVA) were perform to test the difference between cultivar, salicylic concentration, cold stress and their interaction. When ANOVA showed significant treatment effects, Duncan's multiple range test was applied to compared the means at $(\mathrm{P}<0.05)$ (Steel and Torrie, 1980).

\section{Results}

The cold stress and SA treatments, as well as the interaction of them, showed that there was a significant effect on canola physiological traits (Tables 1,2 and 3). These traits significantly decreased by cold stress treatment and increased by SA application.
As shown in Fig. 1 total Chl content declined during the experiment and the maximum content was observed in first day in both cultivars but cold stress dramatically reduced this parameter in plants. Plants treated with SA showed less decline than non-treated, and concentration of SA was directly related to Chl concentration. The Chl level was greater in $200 \mu \mathrm{M}$ than water spraying; conversely $400 \mu \mathrm{M}$ SA treatment resulted in decreasing this trait.

The content of MDA (as a key for evaluating the membrane oxidation) was upward during the experiment and 'RGS' cultivar in the third day in non-SA treatment had the highest content of MDA. The lowest content of MDA was observed in 'Licord' cultivar, with $200 \mu \mathrm{M}$ SA in first day (Fig. 2).

Antioxidant enzyme activity of SOD was significantly increased in stress condition also the enzyme activity increased with increasing concentration of SA and resistant cultivar in $200 \mu \mathrm{M}$ SA treatment had the highest activity of this enzyme. In third sampling, activity of SOD had slightly increased or even decreased (Fig. 3).

Peroxidase enzyme activities as well as SOD increased in stress condition and during the experiment were an upward. In addition, the plants treated with SA increased the activity of this enzyme compared with no treatment. The highest activity of this enzyme was observed in the third day with $200 \mu \mathrm{M}$ SA treatment in resistant cultivars ('Licord'), but $400 \mu \mathrm{M}$ SA reduced the activity of this enzyme in this cultivar. By contrast, further increase in SA concentration $(400 \mu \mathrm{M})$ in resistance cultivar ('Licord') showed no increase in POX activity at third day (Fig. 4).

The level CAT activity during the experiment was in a downward trend whereas the lowest activity was observed in the 'RGS' cultivars with $200 \mu \mathrm{M}$ SA application. It is notable that in this treatment, the enzyme activity was increased in third day (Fig. 5).

Protein concentration also decreased affected cold stress and SA spraying was effective in protein content, too. The lowest content was in the 'RGS' cultivar and in non-SA treatment. The content of protein was little

Table 1. Analysis of variance on total Chl, MDA, SOD, CAT,POX, protein and proline of canola genotypes, treated by SA in first day

\begin{tabular}{|c|c|c|c|c|c|c|c|c|}
\hline SOV & $\mathrm{df}$ & Total Chl & MDA & SOD & CAT & POX & PROT & PROL \\
\hline Rep & 2 & $0.0038^{\mathrm{ns}}$ & $0.0008^{\mathrm{ns}}$ & $0.0257^{* *}$ & $0.000066^{\mathrm{ns}}$ & $0.000087^{\text {ns }}$ & $0.415^{\mathrm{ns}}$ & $0.018^{\mathrm{ns}}$ \\
\hline Variety & 1 & $0.0620^{* *}$ & $0.0040^{\mathrm{ns}}$ & $0.000016^{\mathrm{ns}}$ & $0.00041^{\mathrm{ns}}$ & $0.00010^{\mathrm{ns}}$ & $3.62^{\circ}$ & $0.0057^{\mathrm{ns}}$ \\
\hline Concentration & 3 & $0.0199^{\mathrm{ns}}$ & $0.00091^{\mathrm{ns}}$ & $0.0079^{\mathrm{ns}}$ & $0.00016^{\mathrm{ns}}$ & $0.000048^{\text {ns }}$ & $0.74^{\mathrm{ns}}$ & $0.0316^{\mathrm{ns}}$ \\
\hline Interaction & 3 & $0.1445^{* *}$ & $0.00108^{\mathrm{ns}}$ & $0.0044^{\mathrm{ns}}$ & $0.00002^{\mathrm{ns}}$ & $0.0015^{*}$ & $3.28^{* *}$ & $0.0033^{\mathrm{ns}}$ \\
\hline Error & 14 & 0.0068 & 0.0016 & 0.0026 & 0.000104 & 0.00013 & 0.57 & 0.028 \\
\hline CV \% & & 5.68 & 8.54 & 11.25 & 7.26 & 9.36 & 3.86 & 11.70 \\
\hline
\end{tabular}

Table 2. Analysis of variance on total Chl, MDA, SOD, CAT,POX, protein and proline of canola genotypes treated by SA in second day

\begin{tabular}{|c|c|c|c|c|c|c|c|c|}
\hline SOV & $\mathrm{df}$ & Total Chl & MDA & SOD & CAT & POX & PROT & PROL \\
\hline Rep & 2 & $0.0105^{\mathrm{ns}}$ & $0.00030^{\mathrm{ns}}$ & $0.0021^{*}$ & $0.00000038^{* *}$ & $0.000028^{\mathrm{ns}}$ & $0.42^{\mathrm{ns}}$ & $0.0062^{\mathrm{ns}}$ \\
\hline Variety & 1 & $0.0133^{\mathrm{ns}}$ & $0.00018^{\mathrm{ns}}$ & $0.891^{*}$ & $0.00010^{*}$ & $0.000497^{*}$ & $8.56^{* \prime}$ & $20.97^{*}$ \\
\hline Concentration & 3 & $0.024^{*}$ & $0.00046^{\mathrm{ns}}$ & $0.043^{* *}$ & $0.0012^{*}$ & $0.00174^{* *}$ & $3.586^{\circ}$ & $0.74^{* \prime}$ \\
\hline Interaction & 3 & $0.026^{\prime \prime}$ & $0.0035^{\circ}$ & $0.053^{* *}$ & $0.00037^{* *}$ & $0.0019^{*}$ & $1.08^{\mathrm{ns}}$ & $0.147^{\mathrm{ns}}$ \\
\hline Error & 14 & 0.0039 & 0.00066 & 0.00052 & 0.000010 & 0.000024 & 0.44 & 0.0632 \\
\hline $\mathrm{CV} \%$ & & 6.40 & 7.90 & 1.59 & 6.33 & 3.23 & 3.71 & 9.74 \\
\hline
\end{tabular}


Table 3. Analysis of variance on total Chl, MDA, SOD, CAT, POX, protein and proline of canola genotypes treated by SA in third day

\begin{tabular}{ccccccccc}
\hline SOV & df & Chl total & MDA & SOD & CAT & POX & PROT & PROL \\
\hline Rep & 2 & $0.0048^{\text {ns }}$ & $0.00089^{\text {ns }}$ & 0.0068 & $0.000040^{*}$ & $0.0000018^{\text {ns }}$ & $1.28^{\text {ns }}$ & $0.35^{\text {ns }}$ \\
Variety & 1 & $0.0025^{\text {ns }}$ & $0.034^{*}$ & $1.147^{*}$ & $0.0001^{*}$ & $0.0015^{*}$ & 0.58 & $11.10^{*}$ \\
Concentration & 3 & $0.027^{*}$ & $0.025^{*}$ & $0.099^{*}$ & $0.00087^{*}$ & $0.0012^{*}$ & $9.668^{*}$ & $0.96^{*}$ \\
Interaction & 3 & $0.039^{*}$ & $0.0047^{*}$ & $0.0025^{\text {ns }}$ & $0.00002^{\text {ns }}$ & $0.00071^{*}$ & $11.35^{*}$ & $0.273^{\text {ns }}$ \\
Error & 14 & 0.0049 & 0.00033 & 0.0033 & 0.0000089 & 0.000013 & 0.46 & 0.13 \\
CV $\%$ & & 7.02 & 6.83 & 4.13 & 6.98 & 2.47 & 3.99 & 11.86 \\
\hline
\end{tabular}

${ }^{*},{ }^{* *}$ and ns significant at 0.05, 0.001 probability level and no significant, respectively. CAT-Catalase; Chl-Chlorophyll; SA-Salicylic acid; SOD-Superoxide dismutase; POX-Peroxidase
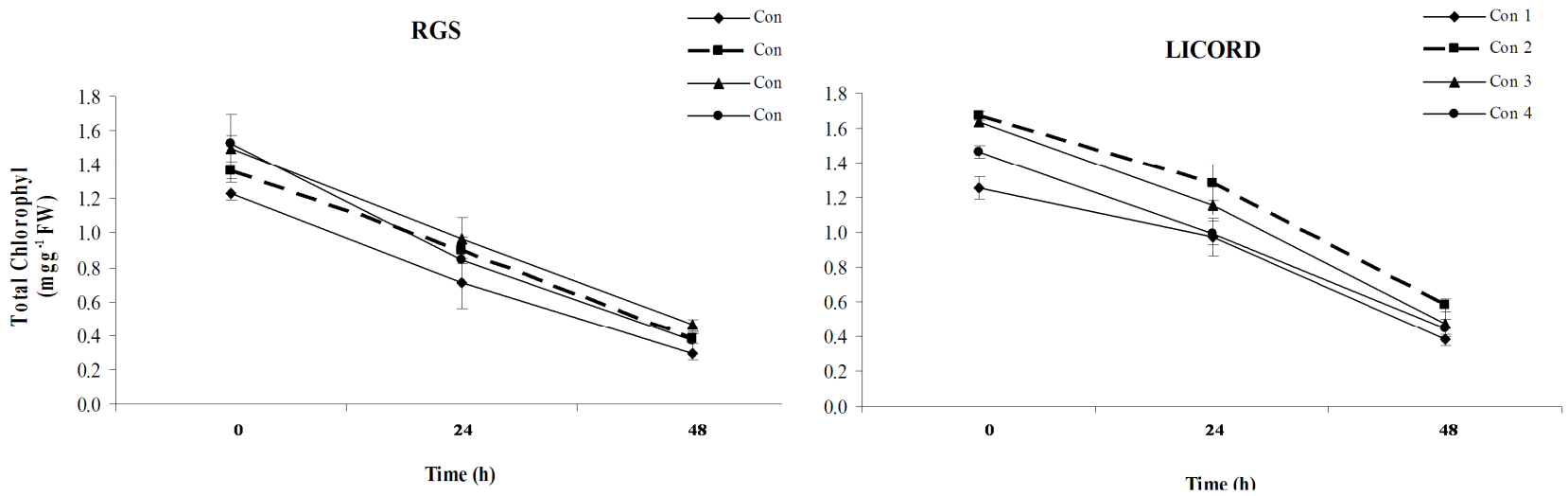

Fig. 1. Effect of different concentration of SA on total Chl content in 'RGS' and 'Licord' cultivars

(Con 1-0 $\mu \mathrm{M} / \mathrm{LSA}$; Con 2-100 $\mu \mathrm{M} / \mathrm{LSA}$; Con 3-200 $\mu \mathrm{M} / \mathrm{LSA}$; Con 4-400 $\mu \mathrm{M} / \mathrm{LSA}$ )
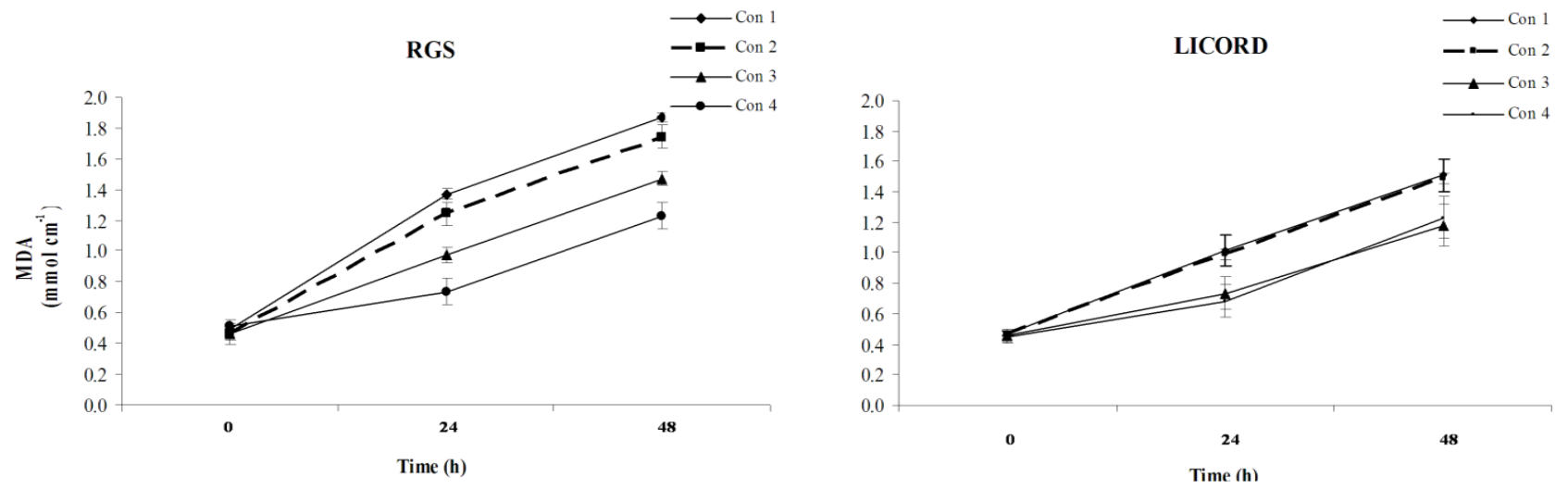

Fig. 2. Effect of different concentration of SA on MDA content in 'RGS' and 'Licord' cultivars

(Con 1-0 $\mu \mathrm{M} / \mathrm{L}$ SA; Con 2-100 $\mu \mathrm{M} / \mathrm{L}$ SA; Con 3-200 $\mu \mathrm{M} / \mathrm{L}$ SA; Con 4-400 $\mu \mathrm{M} / \mathrm{LSA}$ )
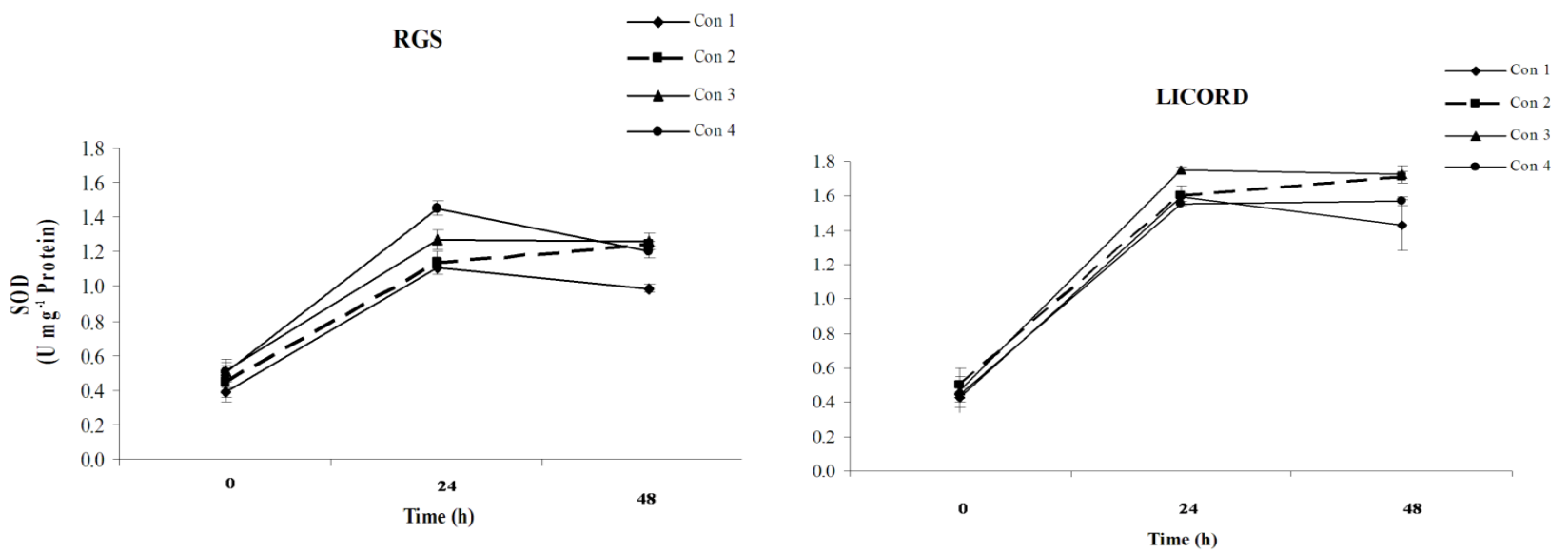

Fig. 3. Effect of different concentration of SA on SOD activity in 'RGS' and 'Licord' cultivars

(Con 1-0 $\mu \mathrm{M} / \mathrm{LSA}$; Con 2-100 $\mu \mathrm{M} / \mathrm{LSA}$; Con 3-200 $\mu \mathrm{M} / \mathrm{L}$ SA; Con $4-400 \mu \mathrm{M} / \mathrm{LSA}$ ) 
102

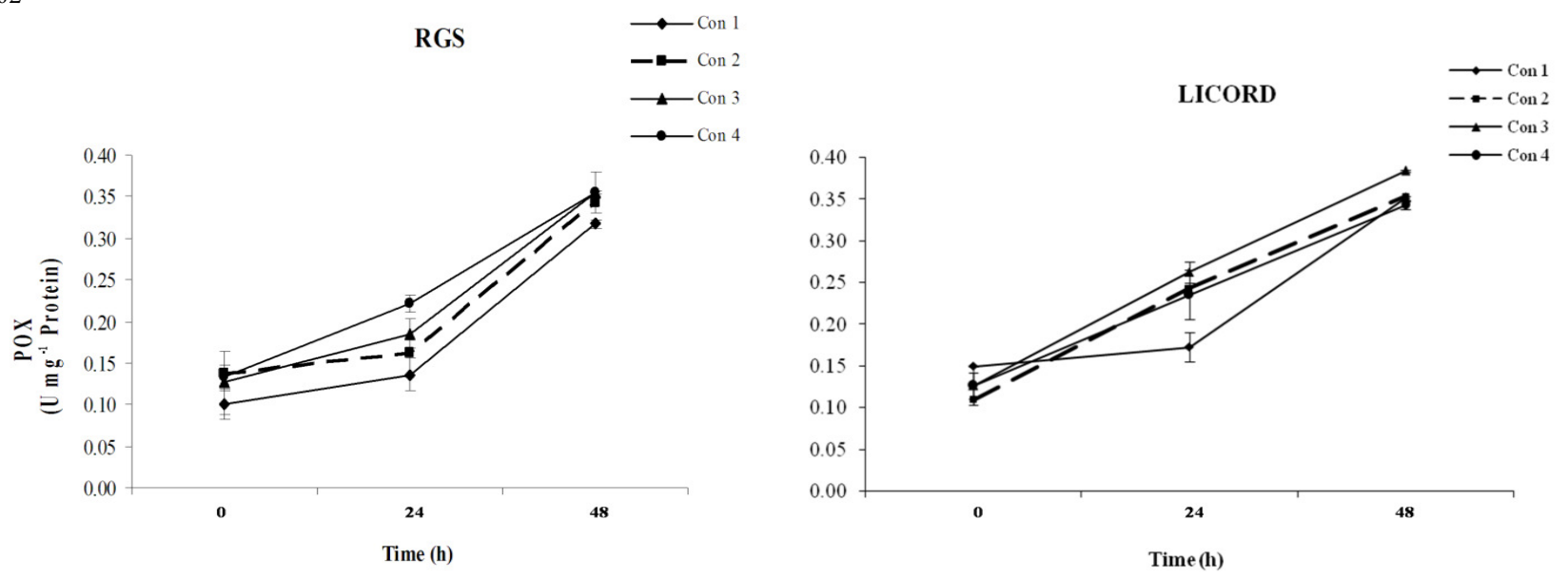

Fig. 4. Effect of different concentration of SA on POX activity in canola

(Con 1-0 $\mu \mathrm{M} / \mathrm{LSA}$; Con 2-100 $\mu \mathrm{M} / \mathrm{L}$ SA; Con 3-200 $\mu \mathrm{M} / \mathrm{L}$ SA; Con 4-400 $\mu \mathrm{M} / \mathrm{LSA}$ )
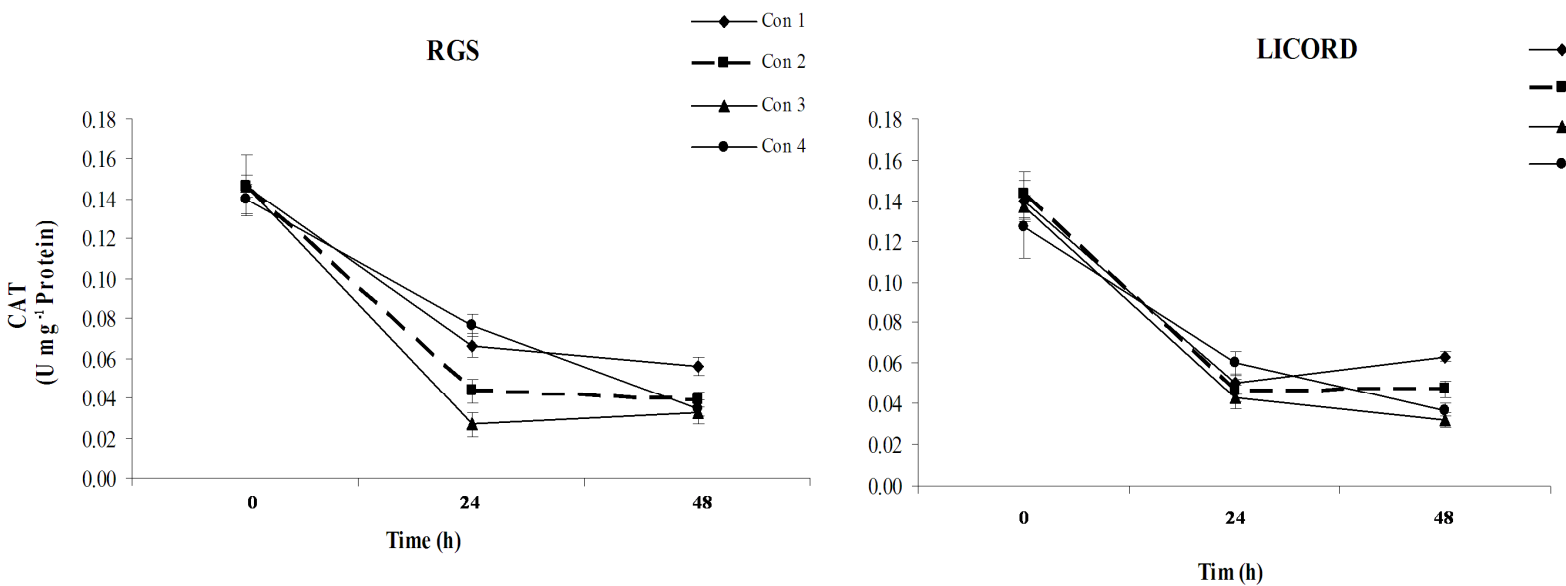

Fig. 5. Effect of different concentration of SA on CAT activity in 'RGS' and 'Licord' cultivars

(Con 1-0 $\mu \mathrm{M} / \mathrm{LSA}$; Con 2-100 $\mu \mathrm{M} / \mathrm{LSA}$; Con 3-200 $\mu \mathrm{M} / \mathrm{LSA}$; Con 4-400 $\mu \mathrm{M} / \mathrm{LSA}$ )
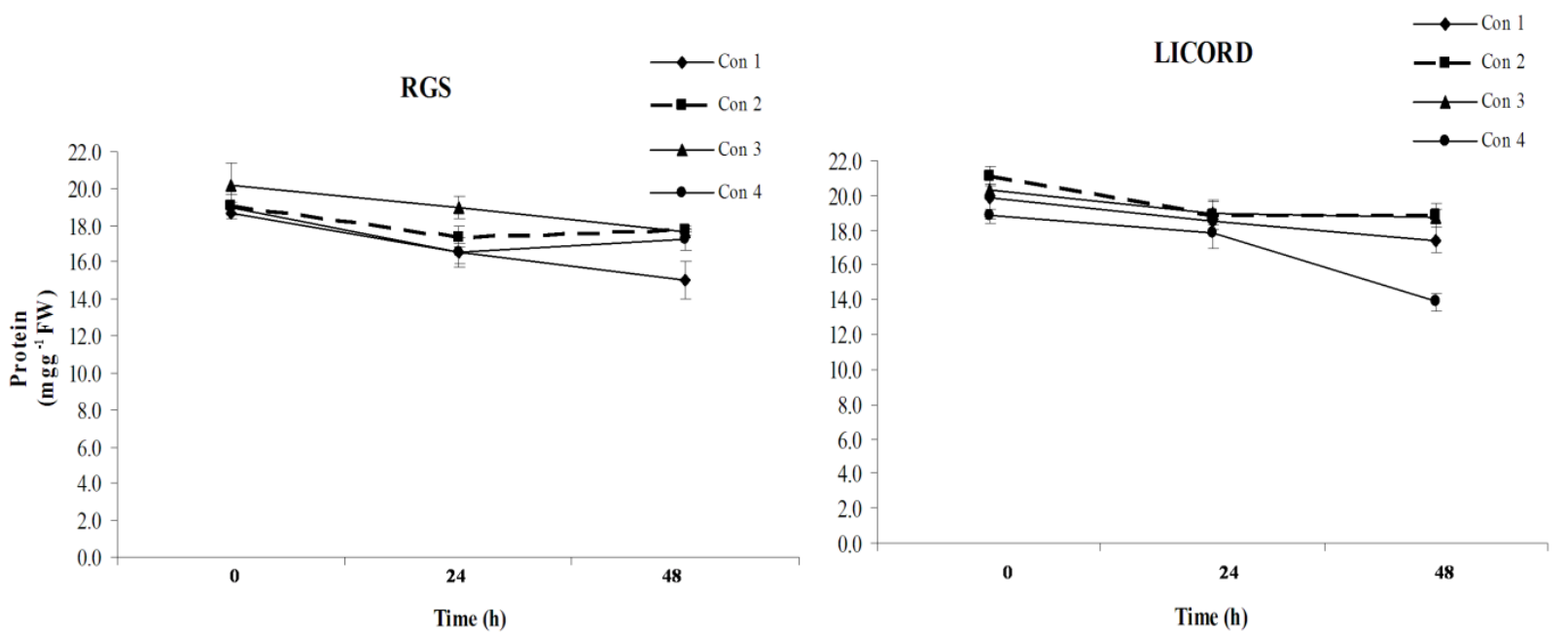

Fig. 6. Effect of different concentration of SA on protein content in 'RGS' and 'Licord' cultivars

(Con 1-0 $\mu \mathrm{M} / \mathrm{L}$ SA; Con 2-100 $\mu \mathrm{M} / \mathrm{L}$ SA; Con 3-200 $\mu \mathrm{M} / \mathrm{LSA}$; Con 4-400 $\mu \mathrm{M} / \mathrm{LSA}$ )

changed in the second day and third day. Although, protein levels were reduced by $400 \mu \mathrm{M}$ SA in 'Licord' cultivar (Fig. 6).

Proline was greatly affected by SA treatment and its content was the highest in third day after treatment with $200 \mu \mathrm{M}$ SA in 'Licord'.
Other concentrations, similar $400 \mu \mathrm{M}$ SA led to increasing in proline content in second day after treatment then decreased.

In 'RGS' genotype, proline content was higher in 400 $\mu \mathrm{M}$ SA than other concentrations and it was the highest in end of the experiment (Fig. 7). 


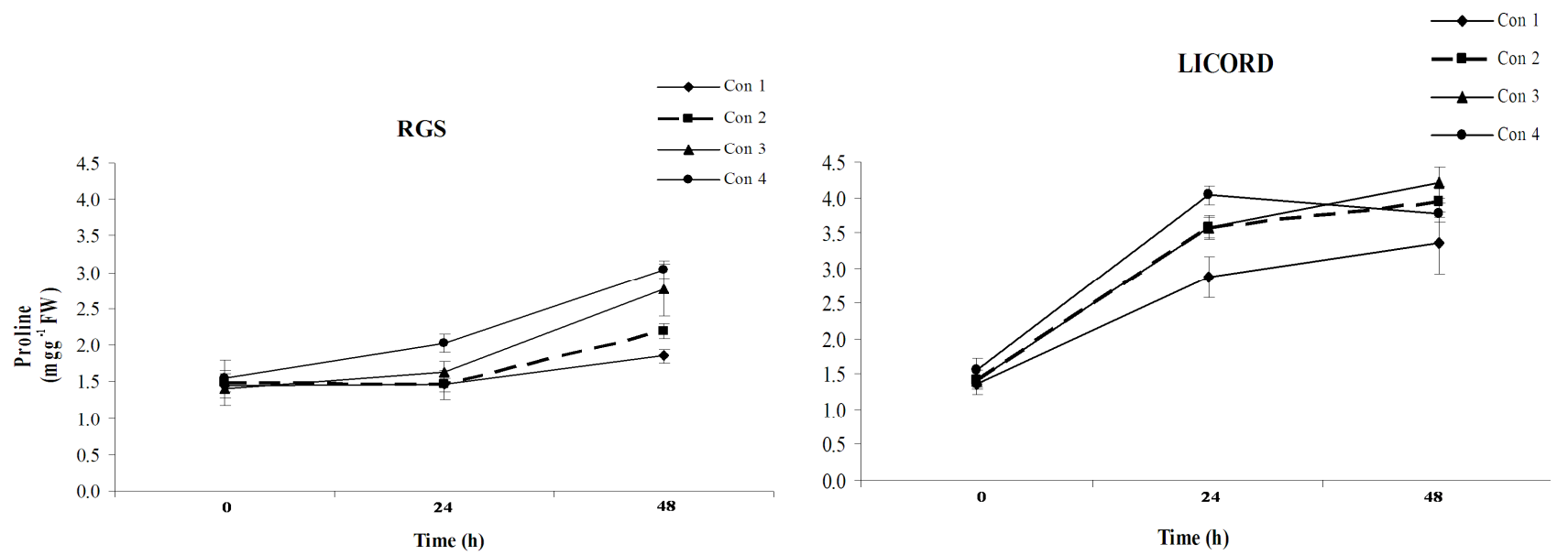

Fig. 7. Effect of different concentration of SA on proline content in 'RGS' and 'Licord' cultivars

(Con 1-0 $\mu \mathrm{M} / \mathrm{LSA}$; Con 2-100 $\mu \mathrm{M} / \mathrm{L}$ SA; Con 3-200 $\mu \mathrm{M} / \mathrm{L}$ SA; Con $4-400 \mu \mathrm{M} / \mathrm{L}$ SA)

\section{Discussion}

The results showed that SA application increased the content of total $\mathrm{Chl}$ in both cultivars. The loss of $\mathrm{Chl}$ is one of the symptoms of oxidative stress (Manafi et al., 2015). Cold stress caused to an increase in free radicals in chloroplast which results in cellular damaging and decline in membrane permeability. Therefore certain metabolic such as carbon fixation might have been affected. Because the reaction of photosynthesis is hindered by stress condition and the excessive light energy cannot be used for the reduction of $\mathrm{NADP}^{+}$, superoxide anion of the ROS is generated (Manafi et al., 2015). To avoid cellular damage, the Chl needs to be degraded quickly. Maybe low temperature leads to increase ROS in chloroplast and caused the Chl molecules destruction and damaged the chloroplast membrane system and photosynthetic reaction centre. Probably, SA as a detoxifier of ROS might prevent the activity of free radicals alleviated the superoxide radicals and can enhance leaf $\mathrm{Chl}$ content. Similar results were reported by Manafi et al. (2015) in soybean and Kang and Saltveit (2002) in maize. Chilling stress causes not only a substantial damage to photosynthetic pigments, but also leads to deterioration to thylakoid membrane. In severe chilling stress condition chlorophyllase increased as a result the chlorophyll content are decreased. The exogenous application of SA, significantly increased the activity of antioxidant system and it's forced a direct impact on the intensity of photosysthesis.

Stress conditions and unfavourable environmental factors induced oxidative stress in plants tissues (Manafi et al., 2015). When chloroplasts are expose to excessive excitation energy, it caused generation of ROS and induce oxidative stress (Tasgin et al., 2003). To prevent damage of free radicals, plants have developed mechanisms by accumulation antioxidant systems (Tasgin et al., 2003). Relatively higher activities of ROS scavenger enzymes have been reported in many plants which suggested that the antioxidant system play an important role in plants against environmental stress (Qaiser et al., 2010).

Recent studies have demonstrated that SOD may function as a ROS scavenger by converting $\mathrm{O}$ to $\mathrm{H}_{2} \mathrm{O}_{2}$, and can lead to enhanced stress tolerance (Manafi et al., 2015). Similar findings were presented under stress condition in higher plants (Horváth et al., 2007). The present results showed that SA induced SOD activation that consistent with results obtained with other various plants species (Kang and Saltveit, 2002). The activity of SOD increased in both cultivars during the whole experiment period that maybe caused of low temperature. Probably, cold condition directly or indirectly lead to production of ROS, which result in increased oxidative stress and SOD, which is one of the key enzymes antioxidant system that scavenger of free radical, converts one form of ROS to $\mathrm{H}_{2} \mathrm{O}_{2}$ (Manafi et al., 2015).

$\mathrm{H}_{2} \mathrm{O}_{2}$ is converted to oxygen and water by CAT and POX which use ascorbate as the hydrogen donor. It is considered that one of the functions of SA is the inhibition of CAT, resulting in $\mathrm{H}_{2} \mathrm{O}_{2}$ accumulation (Dat et al., 1998; Horváth et al., 2002). The current results showed that CAT activity decreased when plants were treated with SA (Fig. 5). Similar results shown that CAT was found to be inhibited in some plant (Dat et al., 1998; Janda et al., 1999). However other reports showed an increases in CAT activity after SA treatment (Horváth et al., 2007). Activities of POX enzyme was also affected by SA treatment (Fig. 4). It has been found that SA has a protective role against ROS and acts as an activated antioxidant system and scavenging free radicals with activated the antioxidant system. These free radicals can damage the protein and nucleic acids (Manafi et al., 2015). It has been observed that leaf activity of SOD and POX increased with increasing in SA concentration that probably low temperature induced oxidative damage. Thus, induction of antioxidative defence mechanisms may reflect the plant response requirement to overcome oxidative injury induced by environmental stress. These findings suggest that an accumulation of ROS may be occurred in response to low temperature and SA by increasing the antioxidant enzymes activity and reduced oxidative injury. Thus, the obtained data demonstrated that activation of antioxidant enzymes induced by the treatment with SA and this contribute to its anti-stress effects in plants. Similarly increase in the activities of SOD (Horváth et al., 2007) and POX (Janda et al., 1999; Kang and Saltveit, 2002) and decrease in CAT activities (Senaranta et al., 2000) has been reported.

Under cold stress conditions, oxidative damage may occur, due to overproduction of ROS (Dat et al., 2000) and rate of neutralizing of ROS by enzymatic antioxidants are essential to maintain the concentration of ROS at relatively low level. 
104

Many reports have confirmed that plants could employ their antioxidative system to alleviate chilling stress induced oxidative injury (Horváth et al., 2007). This observation was supported by the increase of MDA or lipid peroxidation in cold condition. The role of SA has been studied in many physiological processes and reported that exogenous SA could increase environmental tolerance in some plants (Horváth $e t$ al., 2007). The current results suggest that SA application may control the cold induced oxidative stress in canola plants and it is also associated with the raising of total SOD and POX activity and decreased in accumulation of MDA.

Low level of protein in treated plants with distillation maybe related to oxidative damage which mediated the degradation of proteins (Noctor and Foyer, 1998). Probably SA by neutralization of free radicals prevented the destruction of protein and leads to increasing in leaves protein solution.

In a wide range of environmental stress, free proline expands and it is established that proline is a highly water soluble amino acid (Manafi et al., 2015) and are involved in the succession resistant capability of plants (Parvanova et al., 2004). Recently it has been reported that increasing the level of proline in transgenic tobacco lead to increased tolerance in high level of cold stress (Parvanova et al., 2004). Winter wheat with high level of proline has greater tolerance in chilling stress (Doerffling et al., 1993). In addition Galiba (1994) reported direct correlation between proline level and chilling tolerance in various species. The present results showed that the greatest level of obtained proline was in third and second day after treatment in 'Licord' and 'RGS', respectively.

The present findings showed that suitable concentration of SA activated antioxidant activities; however, higher concentration of SA, inversely depressed activity of antioxidative enzymes. The chilling stress affected the biochemical process and reduced photosynthetic pigments. Application of SA can increased the antioxidant activity in canola than compared to untreated plants. Use of SA can reduces the destructive effect of chilling stress and it was shown that $200 \mu \mathrm{M}$ had better result on physiological process.

\section{References}

Arivalagan M, Somasundaram R (2015). Effect of propiconazole and salicylic acid on the growth and photosynthetic pigments in Sorghum bicolor (L.) Moench under drought condition. Journal of Ecobiotechnology 7:17-23.

Arnon DI (1949). Copper enzymes in isolated chloroplasts, polyphennoloxidase in Beta vulgaris. Plant Physiology 24:1-150.

Bates LS, Waldern RP, Teave ID (1973). Rapid determination of free proline for water stress studies. Plant Soil 39:205-207.

Bradford MA (1976). Rapid and sensitive method for the quantitation of protein utilizing the principle of protein-dye binding. Annual Review of Biochemistry 72:248-254.

Cakmak I, Horst W (1991). Effect of aluminium on lipid peroxidation, superoxide dismutase, catalase and peroxidase activities in root tip of soybean (Glycinemax). Plant Physiology 83:463-468.

Dat JF, Lopez-Delgado H, Foyer CH, Scott IM (1998). Parallel changes in $\mathrm{H}_{2} \mathrm{O}_{2}$ and catalase during thermotolerance induced by salicylic acid or heat acclimation in mustard seedlings. Plant Physiology 116:1351-1357.
Dat JF, Lopez-Delgado H, Foyer CH, Scott IM (2000). Effects of salicylic acid oxidative stress and thermotolerance in tobacco. Plant Physiology 156:659-665.

Doerffling K, Doerffling H, Lesselich G (1993). In vitro selection and regeneration of hydroxyproline-resistant lines of winter wheat with increased praline content and increased frost tolerance. Plant Physiology 142:222-225.

Ebrahimia M, Khajehpourb MR, Naderic AB, Majde Nassirid B (2014). Physiological responses of sunflower to water stress under different levels of zinc fertilizer. International Journal of Plant Production 8:483-504.

Galiba $G$ (1994). In vitro adaptation for drought and cold hardiness in wheat. Plant Breeding Reviews 12:115-162.

Ghanati F, Morita A, Yokota H (2002). Induction of suberin and increase of lignin content by excess boron in tobacco cell. Soil Science. Plant Nutrition 48:357-364.

Giannopolitis C, Ries S (1977). Superoxide dismutase I. Occurrence in higher plants. Plant Physiology 59:309-314.

Horváth E, Janda T, Szalai G, Páldi E (2002). In vitro salicylic acid inhibition of catalase activity in maize: differences between the isozymes and a possible role in the induction of chilling tolerance. Plant Science 163:1129-1135.

Horváth E, Szalai G, Janda T (2007). Induction of abiotic stress tolerance by salicylic acid signalling. Plant Growth Regulation 26:290-300.

Janda T, Szalai G, Tari I, Páldi E (1997). Exogenous salicylic acid has an effect on chilling symptoms in maize (Zea mays L.) plants. In: Sowinski P, Zagdanska BA, Aniol P, Klaus (Eds). Crop development for cool and wet European climate. ECSP-EECEAEC, Brussels, Belgium pp 179-187.

Janda T, Szalai G, Tari I, Paldi E (1999). Hydroponic treatment with salicylic acid decrease the effects of chilling injury in maize (Zea mays L.) plants. Planta 208:175-180.

Kang HM, Saltveit ME (2002). Chilling tolerance of maize, cucumber and rice seedling leaves and roots are differentially affected by salicylic acid. Physiology Plant 115:571-576.

Manafi E, Modarres Sanavy SAM, Aghaalikhani M, Dolatabadian A (2015). Exogenous 5-Aminolevulenic Acid Promotes Antioxidative Defence System, Photosynthesis and Growth in Soybean against Cold Stress. Notulae Scientia Biologicae 7(4):486-494.

Mishra A, Choudhuri MA (1999). Effects of salicylic acid on heavy metal induced membrane degradation mediated by lipoxigenase in rice. Biology Plant 42:409-415.

Mohamadi N, Rajaei P (2013). Effect of Triamidefon fungicide on some growth parameters and antioxidant enzymes activity in tomato (Lycopersicom esculentum Mill.) plant under drought stress. International journal of Advanced Biological and Biomedical Research 1:341-50.

Noctor G, Foyer CH (1998). Ascorbate and glutathione: Keeping active oxygen under control. Annual Review of Plant Physiology and Plant Molecular Biology 49:249-279.

Parvanova D, Ivanov S, Konstantinova T, Karanov E, Atanassov A, Tsvetkon T, Alexieva V, Djilianov D (2004). Transgenic tabacco plants accumulating osmolytes show reduced oxidative damage under freezing stress. Plant Physiology and Biochemistry 42:57-63. 
Qaiser H, Shamsul H, Mohd I, Aqil A (2010). Effect of exogenous salicylic acid under changing environment. A review Environmental and Experimental Botany 68:14-25.

Raskin I (1992). Role of salicylic acid in plants. Annual Review of Plant Physiology and Plant Molecular Biology 43:439-463.

Ruelland E, Pokotylo I, Djafi N, Cantrel C, Repellin A, Zachowski A (2016). Corrigendum: Salicylic acid modulates levels of phosphoinositide dependent-phospholipase C substrates and products to remodel the Arabidopsis suspension cell transcriptome. Plant Science http://dx.doi.org/10.3389/fpls.2016.00036.

Senaranta T, Touchell D, Bunn E, Dixon K (2000). Acetyl salicylic acid (aspirin) and salicylic acid induce multiple stress tolerance in bean and tomato plant. Plant Growth Regulation 30:157-161.

Singh B, Usha K (2003). Salicylic acid induced physiological and biochemical changes in wheat seedlings under water stress. Plant Growth Regulation 39:137-141.
Szepesi Á, Csiszár J, Bajkán S, Gémes, K, Horváth F, Erdei L, Deér, A, Simon LM, Tari I (2005). Role of salicylic aicd pre-treatment on the acclimation of tomato plants to salt and osmotic stress. Acta Biology Szegediensis 49:123-125.

Tasgin E, Atici O, Nalbantoglu B (2003). Effects of salicylic acid and cold on freezing tolerance in winter wheat leaves. Plant Growth Regulation 41:231-236.

Wang Hao Z, Yu Zhen C, Cun Fu L (2007). Differences in biochemical responses to cold stress in two contrasting varieties of rape seed (Brassica napus L.). Study China 9(2):142-146.

Yamamuro C, Zhu JK Yang Z (2016). Epigenetic modifications and plant hormone action. Molecular Plant Review Papers 9:57-70. 